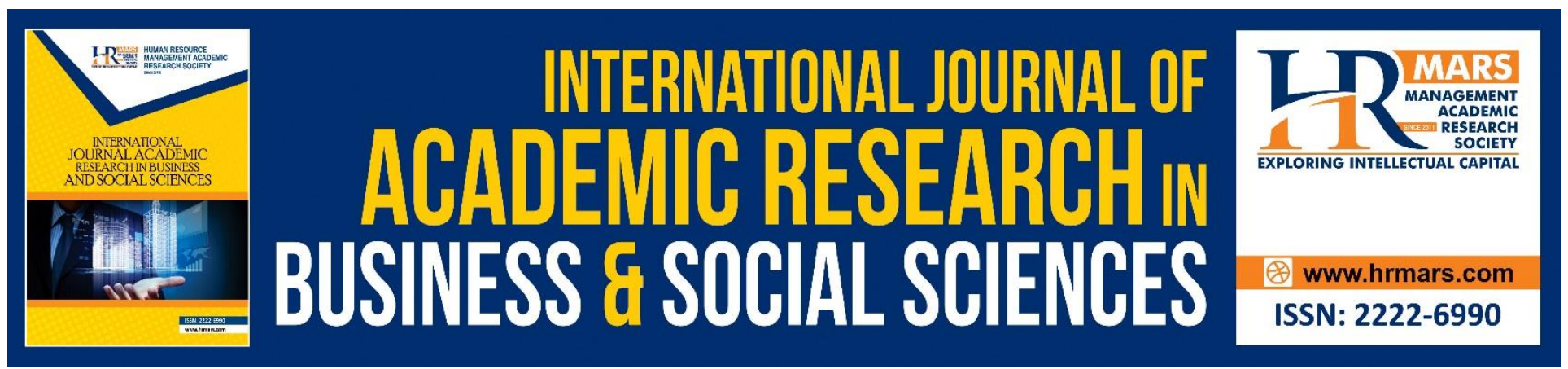

\title{
CF@ER Instrument Validity and Reliability Using Exploratory Factor Analysis
}

Rohaida Muslim, Nurul Fadly Habidin and Nor Azrin Md Latip

To Link this Article: http://dx.doi.org/10.6007/IJARBSS/v10-i7/7597

DOI:10.6007/IJARBSS/v10-i7/7597

Received: 16 April 2020, Revised: 12 May 2020, Accepted: 19 June 2020

Published Online: 17 July 2020

In-Text Citation: (Muslim et al., 2020)

To Cite this Article: Muslim, R., Habidin, N. F., \& Latip, N. A. M. (2020). CF@ER Instrument Validity and Reliability Using Exploratory Factor Analysis. International Journal of Academic Research in Business and Social Sciences, 10(7), 683-696.

\section{Copyright: (C) 2020 The Author(s)}

Published by Human Resource Management Academic Research Society (www.hrmars.com)

This article is published under the Creative Commons Attribution (CC BY 4.0) license. Anyone may reproduce, distribute, translate and create derivative works of this article (for both commercial and non-commercial purposes), subject to full attribution to the original publication and authors. The full terms of this license may be seen at: http://creativecommons.org/licences/by/4.0/legalcode

Vol. 10, No. 7, 2020, Pg. 683 - 696

Full Terms \& Conditions of access and use can be found at http://hrmars.com/index.php/pages/detail/publication-ethics 


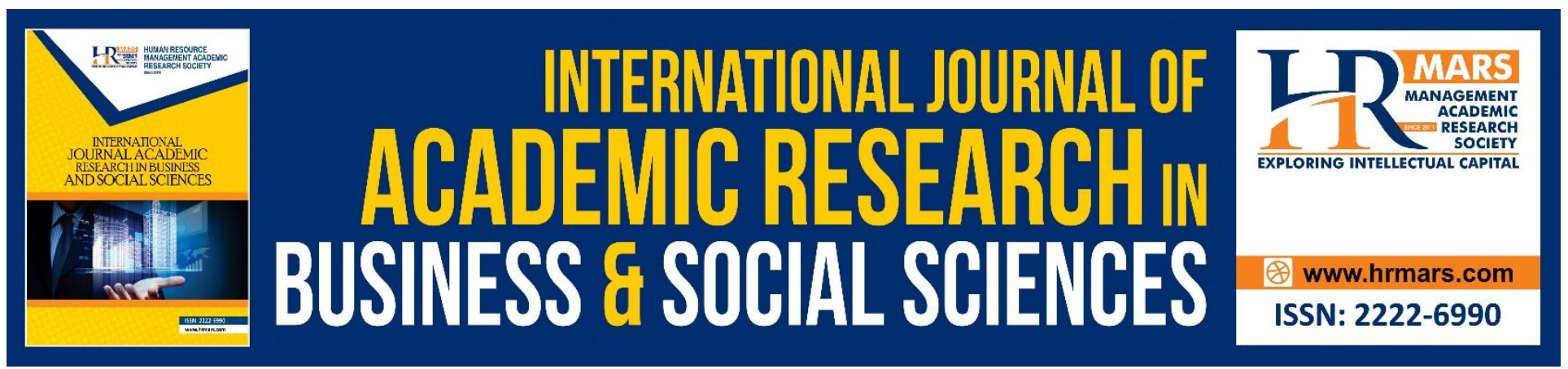

\title{
CF@ER Instrument Validity and Reliability Using Exploratory Factor Analysis
}

\author{
Rohaida Muslim, Nurul Fadly Habidin and Nor Azrin Md Latip \\ Faculty of Management and Economics, Universiti Pendidikan Sultan Idris, 35900 Tanjung Malim, \\ Perak, Malaysia. \\ Email: rohaida2811@gmail.com
}

\begin{abstract}
Research was undertaken to demonstrate the analytical reliability and validity of the Conceptual Framework for Entrepreneurial Resilience (CF@ER) questionnaire. A survey of 150 students from the Business Management Course was performed at one matriculation college in the Northern Region of Malaysia. The reliability and validity of the CF@ER questionnaire was tested using version 23 of the Social Sciences Statistical Package (SPSS) of Cronbach's Alpha and Exploratory Factor Analysis (EFA) respectively. The CF@ER questionnaire is a list of 36 items on a 5-point Likert-scale. The Cronbach alpha analysis shows the total score was 0.843 which demonstrates that the instruments items are highly reliable. Using abstraction of key component information and rotation with Varimax, EFA was then carried out with the validity components. There were 30 items left over for the factor loads above 0.5. The factor analysis suggests that the CF@ER has developed six factors, namely: personal competence, high standards and tenacity (PHT), trust in one's instincts, tolerance to negative affect and the strengthening effects of stress (TTS), positive acceptance of change and secure relationships (PS), control (C), spiritual influences (S) and entrepreneurial intention (EI). The findings of CF@ER would be of interest to educational practitioners in setting up a program of entrepreneurial teaching. Keywords: CF@ER, Cronbach's Alpha, Exploratory Factor Analysis, Reliability, Validity.
\end{abstract}

\section{Introduction}

While these are two separate factors, validity and reliability are intertwined in the assessment of the consistency of the study. According to Kirk and Miller (1986), the reliability of quantitative research generally focuses on two situations: (1) the coherence of the measure; despite multiple repetitions; and (2) the consistency measure throughout all times. In addition, a measure of stability or consistency may be defined as the reliability of the measurement procedures. As shown by Bolarinwa (2015), reliability relates to how replicable the findings of the calculation and the procedure can be. However, the reliability index of the instrument can be obtained using Cronbach's alpha. Furthermore, the range of the index of reliability is between zero $(\alpha=0)$ and one $(\alpha=1)$, and the large alpha value contributes to greater reliability. Fraenkel and Wallen (1996) argued that the reliability item could be accepted if the alpha is from .70 to .99, whereas Pallant (2000) noted that the .7 or 
higher alpha index is good for instruments with 10 or more items. In addition, Kubiszyn and Borich (2003) proposed the acceptability of the $\alpha$ value within the range of .80 to .90 . However, according to Ghazali (2008) in Mohamad et al. (2015), the satisfactory value in social science is .60, which is sometimes practiced through other researchers.

However, the degree whereby the calculation tests what that really supposed to be measured is reflected in its validity (Bolarinwa, 2015). Besides that, validity is defined as a tool of appropriateness, truthfulness, relevance and usefulness for inferencing data (Fraenkel \& Wallen, 1996 in Ghazali \& Sufean, 2016). This research is using the Exploratory Factor Analysis (EFA) tests to assess the instrument 's validity. Chua (2014) reported that EFA was conducted within the constructs to identify and organize a large number of questionnaire items within a particular variable. In addition to the one suggested by Hair, Black, \& Babin (2010), EFA was to be performed to create a latentdimensional structure among the variables expressed in the instrument item. Therefore, this research was carried out using the Exploratory Factor Analysis and Cronbach's alpha to provide empirical proof of the CF@ER questionnaire validity and reliability.

In this paper, there are six domain constructs in the CF@ER questionnaire, namely (1) personal competence, high standards, and tenacity (PHT); (2) trust in one's instincts, tolerance to negative affect and the strengthening effects of stress (TTS); (3) positive acceptance of change and secure relationships (PS); (4) control (C); (5) spiritual influences (S); and (6) entrepreneurial intention (EI).

This paper reviews the literature on ER measures in the next section, as well as RE 's effect on El. Next in Section 3, the researcher focuses further on methods, exploratory factor analysis and outcomes and the future plan for study and practice is to be discussed as a conclusion to this section.

\section{Literature Review}

\section{Resilience (RE)}

RE refers to the ability of individuals to effectively adapt to massive changes, hardships or threats (Duchek, 2018). In particular, this research looked at resilience in the business sense. Based on Awotoye and Singh (2017), RE indicates the ability to address high-impact entrepreneurial barriers to entrepreneurship and to succeed in the entrepreneurial cycle in the face of unexpected circumstances, unforeseen outcomes and significant risks. RE is therefore closely linked to entrepreneurship. In reality, according to Bullough and Renko (2013), in adverse circumstances, entrepreneurship is largely dependent on the awareness of entrepreneurs and RE in the face of adversity. In fact, as individuals doing business in dynamic environments, we need to challenge the status quo and create new paths to development. Without RE, it would be hard for individuals to involve in the entrepreneurship or entrepreneurial activity needed to start a new company (Bullough \& Renko, 2013). In addition, individuals with RE seem to be more likely to recognize with environmental sustainability from a social cognitive theory perspective, and there own RE and optimism eventually be able to participate in entrepreneurial success. At almost the same time, in the context of social exchange relationships (e.g. between individuals and the environment) based on the theory of social exchange, individuals with RE might be a little more likely to agree with the idea of environmental sustainability because, in their perception, attaining enlightenment mostly with environment, given its costs, would go to them for more long-term benefits, such as a great reputation for their business. 
INTERNATIONAL JOURNAL OF ACADEMIC RESEARCH IN BUSINESS AND SOCIAL SCIENCES

Vol. 10, No. 7, July, 2020, E-ISSN: 2222-6990 @ 2020 HRMARS

In brief, RE has a significant impact on entrepreneurship, and RE people are much more likely to embrace sustainability and behavioral improvement. Malaysian Matriculation College should then delegate five factor scales to CF@ER in order to measure student RE.

\section{Personal Competence, High Standards and Tenacity (PHT)}

Based on Connor and Davidson (2003), PHT stresses its resilience in the face of losses and commitment to one's objectives. According to Zautra et al. (2010), PHT relates to the ability to rebound quickly and effectively from a crisis. According to Singh and Yu (2010), in the face of disadvantaged circumstances, PHT reinforces one's sense of control and loyalty to one's goals.

\section{Trust in One's Instincts, Tolerance of Negative Affect, and Strengthening Effects of Stress (TTS)}

Filled with uncertainty, TTS reflects on one's state of mind, decision-making and speed (Connor \& Davidson 2003). According to Ungar et al. (2007), TTS blends personal interests and feelings with a sense of responsibility towards the greater good. Based on Singh and Yu (2010), when coping with uncertainty, TTS focused on one's calmness, judgment and promptness.

\section{Positive Acceptance of Change, and Secure Relationships (PS)}

Connor and Davidson (2003) have found that PS is related to one's adaptability. According to Ungar et al. (2007), PS refers to expectations and the ability of self-care and others to affect changes in one's social and physical setting. Whereas PS is primarily linked to one's own adaptability based on Singh and Yu (2010).

\section{Control (C)}

Connor and Davidson (2003) found out that $C$ is a tacit individual to accomplish his or her own aims and to obtain the support of others. According to Rutter (2008), C is the ability to respond rapidly and rebound from an accident or catastrophe. In fact, Singh and Yu (2010) proposed that C fulfill its own goal and the capacity of others to access support (social assistance). In comparison, Leonie, Margaret, Nicholas \& Yvette (2017) said that individuals with a more internally focused C locus often had a RE profile that was more conducive to better dealing with stressors.

\section{Spiritual Influences (S)}

Centered on Connor and Davidson (2003), S refers to the faith of a person who believes in God or in his destiny. It deals with the capacity to self-assess one 's abilities and shortcomings, ambitions, beliefs and principles, such as spiritual and religious identity, according to Ungar et al. (2007). Singh and $\mathrm{Yu}$ (2010) suggested that S measured one's confidence in God or one's fate. In addition, spirituality has also been developed to boost resilience (Khosravi \& Nikmanesh, 2014).

\section{Entrepreneurial Intention (EI)}

The El reflects a state of mind that encourages one to work alone (Gerba, 2012; Karimi et al ., 2016). The El may be described as an individual commitment or intention to start a new business (Dinis et al., 2013). This further addresses the behavior and commitment of individuals who have been motivated or persuaded to launch a new enterprise (Gerba, 2012). Existing study has indicated that this would be a important effect of TPB ( Ajzen, 1991; Krueger, 2002; Edelman et al., 2008), and 
INTERNATIONAL JOURNAL OF ACADEMIC RESEARCH IN BUSINESS AND SOCIAL SCIENCES Vol. 10, No. 7, July, 2020, E-ISSN: 2222-6990 @ 2020 HRMARS

several of these literatures examine whether students in other universities and institutes are facing the challenge of entrepreneurship.

In cross-cultural research in four countries, Lee et al. (2005) reported that new university students would be involved in entrepreneurship when every country could have sufficient entrepreneurship education. In addition, Wang and Wong (2004) investigate certain interests among Singaporean entrepreneurship students on the basis of their personal history and consider that gender, level of education and family business experience are an significant factor that explains the business interests of students.

An significant cognitive mechanism of RE Entrepreneurship will therefore attain entrepreneurial success (Ayala \& Manzano, 2010). High impact changes impacted the company's performance by deciding its longevity and growth, especially during the first five years (Awotoye \& Singh, 2017). A proactive entrepreneur can always make a decision that shows an positive outlook and willingness to ensure that the business continues to survive and succeed in a difficult situation. Ayala and Manzano (2014) challenged the validity of RE in entrepreneurship and observed that RE predicted entrepreneurial progress. Table 1 demonstrates the Entrepreneur Resilience (ER) Construct.

Table 1 Constructs of entrepreneurial resilience (ER)

\begin{tabular}{|c|c|c|c|}
\hline Constructs & Domain & $\begin{array}{l}\text { Number of } \\
\text { item }\end{array}$ & Adapted \\
\hline 1 & $\begin{array}{l}\text { Personal Competence, High } \\
\text { Standards, and Tenacity (PHT) }\end{array}$ & 8 items & Connor \& Davidson (2003) \\
\hline 2 & $\begin{array}{l}\text { Trust In One's Instincts, } \\
\text { Tolerance To Negative Affect } \\
\text { and The Strengthening Effects } \\
\text { Of Stress (TTS) }\end{array}$ & 7 items & Connor \& Davidson (2003) \\
\hline 3 & $\begin{array}{l}\text { Positive Acceptance Of Change } \\
\text { and Secure Relationships (PS) }\end{array}$ & 5 items & Connor \& Davidson (2003) \\
\hline 4 & Control (C) & $\begin{array}{l}5 \text { items } \\
\text { ( } 3 \text { original } \\
\text { items) } \\
\text { ( } 2 \text { new items) }\end{array}$ & $\begin{array}{l}\text { Connor \& Davidson (2003) } \\
\text { Leonie, Margaret, Nicholas \& } \\
\text { Yvette (2017) }\end{array}$ \\
\hline 5 & Spiritual Influences (S) & $\begin{array}{l}5 \text { items } \\
\text { ( } 2 \text { original } \\
\text { items) } \\
\text { ( } 3 \text { new items) }\end{array}$ & $\begin{array}{l}\text { Connor \& Davidson (2003) } \\
\text { Khosravi \& Nikmanesh (2014) }\end{array}$ \\
\hline 6 & Entrepreneurial Intention (EI) & 6 items & Linan \& Chen (2009) \\
\hline
\end{tabular}


INTERNATIONAL JOURNAL OF ACADEMIC RESEARCH IN BUSINESS AND SOCIAL SCIENCES

Vol. 10, No. 7, July, 2020, E-ISSN: 2222-6990 @ 2020 HRMARS

\section{Methodology}

\section{Sample and Data Collection}

This research has been an investigative study. In December 2019, the research study conducted this investigation involving 150 respondents from the Matriculation College in the northern part of Malaysia. Respondents study Business Management Certificates. Permit to enter the classes was received first from lecturer prior to the study. The researcher then presented himself and explained the aims of the research until the consent letter and the questionnaire were circulated. Every other participant was then questioned, without the help of other students, to read the instructions before answering the questions and to reply individually on the basis of their own opinions. Participants were requested time to answer the questionnaire for around 30 minutes. Eventually, the questionnaire was compiled and the data processing was carried out.

\section{Instrument}

To measure the variables, the study uses an instrument. The questionnaires need to be properly designed to function as an impactful tool for data collection, particularly when questionnaire design affects the rate of response and also the reliability and validity of the data. Zuraidah (2014) claimed that several variables, including work choices, the sequence of questions and the appearances, were considered in designing the questionnaire. This point is supported by Chan and Idris (2017) who say that a short and straightforward language clearly defined among all participants is used to cultivate collaboration and participation of the questionnaire respondents.

The questionnaire survey starts from a covering letter to notify the participants about the nature of the study, ensuring the input is kept confidential. Two parts of the questionnaire on students in the Business Management Course, Part A and Part B. Part A seems to be about participants of the study and And Part $B$ is more about the study constructs. Part $A$ is composed of six statements that require participants to provide basic gender details, race, living spaces, family occupation, part-time work and business matriculation activities.

Within Part B, there are six domains that contain a total of 36 items covering five associated variable constructs and one dependent variable build on entrepreneurial intention (EI).

It 's important to get the true score using the correct number of points on a likert scales. Nevertheless, whether or not to use a midpoint on scale was the question to be answered before deciding on the optimum number of scale points. This is, to determine if the rating scale should be even or odd number. According to Gwinner (2006) in Thompson (2009), while failure to include its midpoint in a measure could improve the accuracy of the response, it was argued, on the other hand, that using an even-numbered scale, it would put the participant at risk, as it was forced to accept a definite choice and increase the propensity of the participants to negatively react.

And such, the odd-numbered measure was employed for this research to calculate the respondents' opinions. The respondents were given a Likert scale of five points. The questions got answers from Likert (1), Strongly Disagree (2), Disagree (3), Neither Agree or Disagree (4), Agree (5), Strongly Agree (Tullis \& Albert 2013). These answers allocate amounts between one and five, respectively.

\section{Data Analysis}

Factor analysis: This study used exploratory factor analysis ( EFA) and Cronbach's alpha to analyze the data as shown in Table 2. 
INTERNATIONAL JOURNAL OF ACADEMIC RESEARCH IN BUSINESS AND SOCIAL SCIENCES Vol. 10, No. 7, July, 2020, E-ISSN: 2222-6990 @ 2020 HRMARS

Table 2 Summary of data analysis method

\begin{tabular}{ll}
\hline Purpose & Applied statistical tests \\
\hline Construct Validity & Factor Analysis: Exploratory Factor Analysis \\
Reliability & Cronbach's Alpha \\
\hline
\end{tabular}

Statistical measurements have been carried out and use the Software for Social Sciences (SPSS) version 23. Items upon this questionnaire which could not surpass a cut of 0.5 factor loadings were omitted for factor analysis. Cross-loaded statements were also dropped. Even factors larger than 1 were removed and with own values maintained.

\section{Exploratory Factor Analysis}

Once the study was finished, the researcher had been checked on the precision of data entry, missing values, normality and outliers. Then, the skewiness and kurtosis coefficients were also checked. This study indicates that almost all values are well under \pm 2 (Garson, 2012) and shows the description of the skewness and courtosis statistics, where all items were distributed relatively normal. In comparison, the figures for each item showed normal $z$ values within the range of \pm 4 were not extreme cases nor outliers. There was no major violation, and the data were appropriate for further review.

Three aspects have been taken into account in determining the suitability of the data for factor analysis: (1) sample size, (2) correlation matrix factorability, and (3) Kaiser-Meyer-Olkin (KMO) sampling suitability measure, or the Bartlett sphericity test. Hair et al . (2010) proposed that the sample sizes for further factor analysis would ideally be more than 100 . Furthermore, according to Tabachnick and Fidell (2007), the number that is considered "comfortable" will reach 300 cases. Consequently, Chua (2014) proposed that the number of possible sizes need to be more than 5 times that of variables. This study used a random sample of 150 respondents to perform the EFA, based on all these parameters about the assessment of the appropriateness of random sample for factor analysis.

According to Hair et al. (2010); Tabachnick \& Fidell (2007); Pallant (2007), when the KaiserMeyer-Olkin (KMO) reaches 0.6 and the Bartlett's Sphericity Test (BTS) is significant at $\alpha<.05$, then the correlation matrix factorability is assumed, this could test the sampling adequacy or test whether the data could be a successful predict. In other words, Maat, Zakaria, Nordin, \& Meerah (2011) reported that the KMO test and BTS are evaluating out whether sample became adequate for carrying out the factor analysis. Additionally, Hair et al . ( 2010); Coakes, Steed, Coakes, \& Steed (2003) demonstrate that the researcher had to take into account a few measures as the anti-image correlation should be above 0.5 , the appropriate level for all items. Furthermore, the measurements must be above 0.3 (Tabachnick and Fidell , 2007), in order to accomplish anything. The Exploratory Factor Analysis correspondence index is given in Table 3. 
INTERNATIONAL JOURNAL OF ACADEMIC RESEARCH IN BUSINESS AND SOCIAL SCIENCES Vol. 10, No. 7, July, 2020, E-ISSN: 2222-6990 @ 2020 HRMARS

Table 3 Correspondence index to analyze exploratory factor

\begin{tabular}{|c|c|c|}
\hline Indicators & Cut-off Value & Source \\
\hline $\begin{array}{l}\text { Kaiser-Meyer-Olkin (KMO) } \\
\text { Meritorious: } \geq 0.80, \\
\text { Middling: } \geq 0.70 \\
\text { Mediocre: } \geq 0.60 \\
\text { Miserable: } \geq 0.50, \\
\text { Unacceptable: }<0.50\end{array}$ & $\begin{array}{l}\text { Recommended value of } \\
0.6 \\
\text { or above }\end{array}$ & Hair et al. (2010) \\
\hline Bartlett's Test of Sphericity & Significant at $\alpha<.05$ & Hair et al. (2010) \\
\hline $\begin{array}{l}\text { Anti-Image Correlation: } \\
\text { individual measure of } \\
\text { sampling adequacy (MSA) }\end{array}$ & $>0.5$ & $\begin{array}{l}\text { Hair et al., (2010); Coakes \& } \\
\text { Steed, (2003) }\end{array}$ \\
\hline $\begin{array}{l}\text { Communalities (variables } \\
\text { are well defined by the } \\
\text { solution-low values } \\
\text { require removal) }\end{array}$ & $\begin{array}{l}>0.3 \\
>0.4 \\
>0.5\end{array}$ & $\begin{array}{l}\text { Gaskin (2012); Hair et al. } \\
\text { (2010); Tabachnick \& Fidell } \\
\text { (2007) }\end{array}$ \\
\hline $\begin{array}{l}\text { Factor loadings } \\
\text { Significant Factor Loading } \\
\text { based on Sample Size }\end{array}$ & $\begin{array}{l}\text { Above sufficient loading } \\
\text { factor to maintain the } \\
\text { item while under enough } \\
\text { loading factor to remove } \\
\text { the item. }\end{array}$ & Hair et al. (2010) \\
\hline
\end{tabular}

\section{Findings}

The results obtained from the reliability analysis provided in Table 4 showed that the mean total value, standard deviation and Alpha of Cronbach, before the EFA was completed, amounted to $3,8476,0,31597$ and 0,843 each. Both Cronbach alpha of the six constructs (36 items) exceeded 0.6 from 0.620 to 0.836 . 
INTERNATIONAL JOURNAL OF ACADEMIC RESEARCH IN BUSINESS AND SOCIAL SCIENCES Vol. 10, No. 7, July, 2020, E-ISSN: 2222-6990 @ 2020 HRMARS

Table $4 \quad$ Value mean, Standard deviation and reliability for each construct

\begin{tabular}{llll}
\hline Construct & Mean & Standard Deviation & Reliability \\
\hline $\begin{array}{l}\text { Personal Competence, High Standards, } \\
\text { and }\end{array}$ & 3.9300 & 0.43410 & 0.828 \\
$\begin{array}{l}\text { Tenacity (PHT) } \\
\text { Trust In One's Instincts, Tolerance To }\end{array}$ & 4.0724 & 0.56145 & 0.836 \\
$\begin{array}{l}\text { Negative Affect and The Strengthening } \\
\text { Effects Of Stress (TTS) }\end{array}$ & 3.6973 & 0.45213 & \\
$\begin{array}{l}\text { Positive Acceptance Of Change and } \\
\text { Secure Relationships (PS) }\end{array}$ & & & 0.620 \\
Control (C) & 3.7720 & 0.63162 & 0.763 \\
Spiritual Influences (S) & 4.0467 & 0.56112 & 0.765 \\
Entrepreneurial Intention (EI) & 3.4978 & 0.65964 & 0.728 \\
Total & 3.8476 & 0.31597 & 0.843 \\
\hline
\end{tabular}

Exploratory factor analysis started on a set of 36 items of the instrument by conducting KaiserMeyer-Olkin Measure and Bartlett's Sampling Adequacy Test for sphericity test. The sphericity test by Bartlett, an measure of the relation intensity between variables, confirmed the appropriateness of factor analysis. The results had been found to be significant ( $X 2=2395.845)$. The KMO adequacy test provided a value of 0.769 , suggesting that the sample measurements were sufficiently large to calculate the factor structure. For each construction that was above 0.6 with substantial Bartlett sphericity value regulation, the processes were built to the Kaiser-Meyer-Olkin value. These results, based on Huck (2012); Pallant (2007); Tabachnick \& Fidell (2007), suggest here that data would be adequate also for continuation of the factor analysis. In the end, the communities were decided for each item. Communities of the items varied from 0.161 to 0.786. KMO, Communalities, and Bartlett's Test results were reported in Table 5. 
INTERNATIONAL JOURNAL OF ACADEMIC RESEARCH IN BUSINESS AND SOCIAL SCIENCES Vol. 10, No. 7, July, 2020, E-ISSN: 2222-6990 @ 2020 HRMARS

Table $5 \quad$ Kaiser-Meyer-Olkin and Bartlett's test

\begin{tabular}{ll}
\hline Test & Result \\
\hline Bartlett's Test of & 2395.845 \\
Sphericity Approx. Chi-Square (X2) & \\
& \\
Kaiser-Meyer-Olkin (KMO) Measure of Sampling Adequacy & 0.769 \\
& \\
Df & 630 \\
Sig. & 0.00 \\
Communalities (Range) & 0.161 to 0.786 \\
\hline
\end{tabular}

Based on these overall indicators, EFA was then carried out using extraction of main component analysis and rotation of Varimax with 36 items. For this analysis, the minimal load factor was 0.5. As shown in Table 6, these six factors account for 54,658 percent of the variance. The eigenvalues showed that $19.671 \%$ of the variance was explained by the first factor, $12.544 \%$ by the second factor of the variance, $8.223 \%$ by the third factor of the variance, and $5.344 \%$ by the fourth factor. The fifth and sixth factors seem to have their own values of more than one, each of which explained about $4.521 \%$ and $4.355 \%$ respectively. The percentage variance in Squared Loading and Rotation Summits of Squared Loading Extraction is just the same, which explains 54.658\%. Varimax rotation led to the reduction in the variance percentage for factor 1 from $19.671 \%$ to $12.201 \%$, a reduction in the variance percentage for factor 2 from $12.544 \%$ to $11.831 \%$, a shift in the variance percentage for factor 3 from $8.223 \%$ to $8.388 \%$, a change in the variance percentage for factor 4 from $5.344 \%$ to $8.004 \%$, while the percentage of variance wasa changed from $4.521 \%$ to $7.809 \%$ and $4.355 \%$ to $6.426 \%$ for factor 5 and 6 .

Table 6 Summary of total variance explained in exploratory factor analysis (EFA)

\begin{tabular}{|c|c|c|c|c|c|c|c|c|c|}
\hline \multirow[t]{2}{*}{$\begin{array}{l}\text { Compone } \\
\text { nt }\end{array}$} & \multicolumn{3}{|c|}{ Initial Eigenvalues } & \multicolumn{3}{|c|}{$\begin{array}{c}\text { Extraction Sums of Squared } \\
\text { Loadings }\end{array}$} & \multicolumn{3}{|c|}{$\begin{array}{c}\text { Rotation Sums of Squared } \\
\text { Loadings }\end{array}$} \\
\hline & Total & $\begin{array}{c}\% \text { of } \\
\text { Variance }\end{array}$ & $\begin{array}{c}\text { Cumulativ } \\
\text { e \% }\end{array}$ & Total & $\begin{array}{c}\% \text { of } \\
\text { Variance }\end{array}$ & $\begin{array}{c}\text { Cumulativ } \\
\text { e \% }\end{array}$ & Total & $\begin{array}{c}\% \text { of } \\
\text { Varian } \\
\text { ce }\end{array}$ & $\begin{array}{c}\text { Cumulativ } \\
\text { e } \%\end{array}$ \\
\hline 1 & 7.082 & 19.671 & 19.671 & 7.082 & 19.671 & 19.671 & 4.392 & 12.201 & 12.201 \\
\hline 2 & 4.516 & 12.544 & 32.215 & 4.516 & 12.544 & 32.215 & 4.259 & 11.831 & 24.031 \\
\hline 3 & 2.960 & 8.223 & 40.438 & 2.960 & 8.223 & 40.438 & 3.020 & 8.388 & 32.419 \\
\hline 4 & 1.924 & 5.344 & 45.783 & 1.924 & 5.344 & 45.783 & 2.882 & 8.004 & 40.423 \\
\hline 5 & 1.628 & 4.521 & 50.304 & 1.628 & 4.521 & 50.304 & 2.811 & 7.809 & 48.233 \\
\hline 6 & 1.568 & 4.355 & 54.658 & 1.568 & 4.355 & 54.658 & 2.313 & 6.426 & 54.658 \\
\hline
\end{tabular}

Extraction Method: Principal Component Analysis

A total of six items were omitted on the basis of the Rotated Component Matrix, as six items struggled to meet a minimal load factor of 0.5 or higher and won't result in a simple factor structure and produced cross-loaded products. Either as result, a minimum of 30 items are retained. The results 
INTERNATIONAL JOURNAL OF ACADEMIC RESEARCH IN BUSINESS AND SOCIAL SCIENCES Vol. 10, No. 7, July, 2020, E-ISSN: 2222-6990 @ 2020 HRMARS

of the factor analysis showed that the CF@ER produced six factors. The final items for the CF@ER loaded generator are shown in Table 7.

Table 7 Factor loadings based on a principal component analysis extraction with varimax rotation

\begin{tabular}{|c|c|c|c|c|c|c|}
\hline \multirow[t]{2}{*}{ Item } & \multicolumn{6}{|c|}{ Component } \\
\hline & 1 & 2 & 3 & 4 & 5 & 6 \\
\hline B17 & .773 & & & & & \\
\hline B11 & .759 & & & & & \\
\hline B23 & .758 & & & & & \\
\hline B16 & .744 & & & & & \\
\hline B10 & .737 & & & & & \\
\hline B24 & .730 & & & & & \\
\hline B25 & .722 & & & & & \\
\hline B6 & & .741 & & & & \\
\hline B14 & & .723 & & & & \\
\hline B7 & & .679 & & & & \\
\hline B15 & & .648 & & & & \\
\hline B19 & & .588 & & & & \\
\hline B18 & & .583 & & & & \\
\hline B20 & & .574 & & & & \\
\hline $\mathrm{C} 2$ & & & .875 & & & \\
\hline $\mathrm{C} 1$ & & & .844 & & & \\
\hline C4 & & & .780 & & & \\
\hline C5 & & & .722 & & & \\
\hline \multicolumn{7}{|l|}{ C3R } \\
\hline B30 & & & & .685 & & \\
\hline B28 & & & & .652 & & \\
\hline B29 & & & & .634 & & \\
\hline B9 & & & & .604 & & \\
\hline \multicolumn{7}{|l|}{ B22 } \\
\hline \multicolumn{7}{|l|}{ B3 } \\
\hline \multicolumn{7}{|l|}{ B12 } \\
\hline B26 & & & & & .713 & \\
\hline B13 & & & & & .709 & \\
\hline B21 & & & & & .692 & \\
\hline B27 & & & & & .669 & \\
\hline \multicolumn{7}{|l|}{ C6R } \\
\hline B2 & & & & & & .671 \\
\hline B5 & & & & & & .653 \\
\hline B1 & & & & & & .642 \\
\hline B4 & & & & & & .626 \\
\hline B8 & & & & & & \\
\hline
\end{tabular}


INTERNATIONAL JOURNAL OF ACADEMIC RESEARCH IN BUSINESS AND SOCIAL SCIENCES

Vol. 10, No. 7, July, 2020, E-ISSN: 2222-6990 @ 2020 HRMARS

Seven items loaded onto Factor 1 assess Personal Competence, High Standards, and Tenacity (PHT) were based on the outcome of EFA. Factor 2 contained seven items all related to the Trust in One 's Instincts, Tolerance to Negative Affect and The Strengthening Effects of Stress (TTS). Four items were loaded onto Factor 3 and related to Entrepreneurial Intention (EI), their inclination to engage in the field of entrepreneurship and their willingness to start a new venture. The four items loaded on Factor 4 are related to Spiritual Influences (S) and four items loaded on Factor 5 are related to Control (C). The four items for factor 6 concern Positive Acceptance of Change and Secure. (Table 8)

Table 8 The different number of pooled item for each construct after exploratory factor analysis

\begin{tabular}{llll}
\hline Factor & Construct & List of Old Item & List of New Item \\
\hline 1 & $\begin{array}{l}\text { Personal Competence, High } \\
\text { Standards, and Tenacity (PHT) }\end{array}$ & 8 & 7 \\
2 & $\begin{array}{l}\text { Trust In One's Instincts, Tolerance To } \\
\text { Negative Affect and The } \\
\text { Strengthening Effects Of Stress (TTS) }\end{array}$ & 7 & 7 \\
3 & $\begin{array}{l}\text { Positive Acceptance Of Change and } \\
\text { Secure Relationships (PS) }\end{array}$ & 5 & 4 \\
4 & Control (C) & 5 & 4 \\
5 & Spiritual Influences (S) & 5 & 4 \\
6 & Entrepreneurial Intention (EI) & 6 & 4 \\
\hline
\end{tabular}

\section{Conclusion}

Results of Exploratory Factor Analysis have shown that six key factors are involved in generating conceptual framework for entrepreneurial resilience. The six structures are Personal Competence, High Standards, and Tenacity (PHT), Trust in One's Instincts, Tolerance to Negative Affects, and The Strengthening Effects of Stress (TTS), Positive Acceptance Of Change and Secure Relationships (PS), Control (C), Spiritual Influences (S) and Entrepreneurial Intention (EI).

Correlation and regression will therefore be the focus of future work. It is kept hoping that the interesting thing to be discussed in this paper will be a way for researchers to thoroughly investigate RE and El issues among Malaysian matriculation college students.

\section{References}

Ajzen, I. (1991). The theory of planned behavior. Organizational Behavior and Human Decision Processes, 50(2), 179-211.

Awotoye, Y., \& Singh, R. P. (2017). Entrepreneurial Resilience, High Impact Challenges, and Firm Performance. Journal of Management Policy and Practice, 18(2), 28-37.

Ayala, J. C., \& Manzano, G. (2010). Established business owners' success: Influencing factors. Journal of Developmental Entrepreneurship, 15(3), 263-286.

Ayala, J. C., \& Manzano, G. (2014). The resilience of the entrepreneur. Influence on the success of the business. A longitudinal analysis. Journal of Economic Psychology, 42, 126-135. 
INTERNATIONAL JOURNAL OF ACADEMIC RESEARCH IN BUSINESS AND SOCIAL SCIENCES Vol. 10, No. 7, July, 2020, E-ISSN: 2222-6990 @ 2020 HRMARS

Bolarinwa, O. A. (2015). Principles and methods of validity and reliability testing of questionnaires used in social and health science researches. The Nigerian Postgraduate Medical Journal, 22(4), 195-201.

Bullough, A., \& Renko, M. (2013). Entrepreneurial resilience during challenging times. Business Horizons, 56(3), 343-350.

Chua, Y. P. (2014). Statistik Penyelidikan Lanjutan: Ujian Regresi, Analisis Faktor dan Analisis Sem. Malaysia: McGraw Hill (Malaysia) Sdn Bhd.

Coakes, S. J., Steed, L. G., Coakes, S. J., \& Steed, L. G. (2003). Multiple response and multiple dichotomy analysis. SPSS: Analysis without Anguish: Version 11.0 for Windows, 215-224.

Connor, K. M., \& Davidson, J. R. (2003). Development of a new resilient scale: The CornorDavidson Resilience Scale (CD-RISC). Depression and Anxiety, 18(2), 197-212.

Dinis, A., Paço, A. F., Ferreira, J., Raposo, M., \& Rodrigues, R. G. (2013). Psychological characteristics and entrepreneurial intentions among secondary students. Education+Training, 55(8/9), 763-780.

Duchek, S. (2018). Entrepreneurial resilience: a biographical analysis of successful entrepreneurs. International Entrepreneurship and Management Journal, 14(2), 429-455. doi: 10.1007/s11365-017-0467-2

Edelman, L. F., Manolova, T. S., \& Brush, C. G. (2008). Entrepreneurship education: correspondence between practices of nascent entrepreneurs and textbook prescriptions for success. Academy of Management Learning and Education, 7(1), 56-70.

Fraenkel, J. R., \& Wallen, N. E. (1996). How to Design and Evaluate Research. USA: Mc. Fraw-Hill Inc.

Garson, G. D. (2012). Testing statistical assumptions. Asheboro, NC: Statistical Associates Publishing.

Gaskin, J. (2012). Confirmatory Factor Analysis. Retrieved January 17th, 2020, from http://statwiki.kolobkreations.com/index.php?title=Confirmatory_Factor_Analysis\#2nd_Ord er_Factors

Gerba, D. T. (2012). The context of entrepreneurship education in Ethiopian Universities. Management Research Review, Emerald Group Publishing, 35(3/4), 225-244.

Ghazali, D., \& Sufean, H. (2016). Metodologi Penyelidikan Dalam Pendidikan: Amalan dan Analisis Kajian. Kuala Lumpur: Universiti Malaya.

Hair, J. F., Black, W. C., \& Babin, B. J. (2010). RE Anderson Multivariate Data Analysis: A Global Perspective. New Jersey: Pearson Prentice Hall.

Huck, S. W. (2012). Reading Statistics and Research. 6th Edition. UK: Pearson.

Karimi, S., Biemans, H. J. A., Lans, T., Chizari, M., \& Mulder, M. (2016). The impact of entrepreneurship education: a study of Iranian students' entrepreneurial intentions and opportunity identification. Journal of Small Business Management, 54(1), 187-209.

Khosravi, M., \& Nikmanesh, Z. (2014). Relationship of spiritual intelligence with resilience and perceived stress. Iranian Journal of Psychiatry and Behavioral Sciences, 8(4), 52-6.

Kirk, J., \& Miller, M.L. (1986). Reliability and Validity in Qualitative Research. US: Sage Publications, Inc.

Krueger, N. F. (2002). Entrepreneurship: Critical Perspectives on Business and Management. Taylor and Francis, Philadelphia, $P A$.

Kubiszyn, T., \& Borich, G. (2003). Educational Testing and Measurement: Classroom Application and Practice. Seventh Edition. US: John Wiley \& Son, Inc. 
INTERNATIONAL JOURNAL OF ACADEMIC RESEARCH IN BUSINESS AND SOCIAL SCIENCES

Vol. 10, No. 7, July, 2020, E-ISSN: 2222-6990 @ 2020 HRMARS

Lee, L., Wong, P. K., Chua, B. L., \& Chen, J. (2005). Antecedents for Entrepreneurial Propensity: findings from Singapore, Hong Kong and Taiwan.

Leonie, K., Margaret, P., Nicholas, G., \& Yvette, K. (2017) Control and resilience: The importance of an internal focus to maintain resilience in academically able students. Gifted and Talented International Journal, 32(1), 59-74, DOI:10.1080/15332276.2018.1435378

Maat, S. M., Zakaria, E., Nordin, N. M., \& Meerah, T. S. M. (2011). Confirmatory factor analysis of the mathematics teachers' teaching practices instrument. World Applied Sciences Journal, 12(11), 2092-2096.

Mohamad, M.M., Sulaiman, N.L., Sern, L.C., \& Mohd Salleh, K. (2015). Measuring the validity and reliability of research instruments. Social and Behavioral Sciences, 204, 164-171.

Pallant, J. (2000). Development and validation of a scale to measure perceived control of internal states. Journal of Personality Assessment, 75(2), 308-337.

Pallant, J. (2007). SPSS survival manual-A step by step guide to data analysis using SPSS for windows. (3rd ed.). Maidenhead: Open University Press.

Rutter, M. (2008). Developing concepts in developmental psychopathology. In J.J.Hudziak (Ed.), Developmental psychopathology and wellness: Genetic and environmental influences (pp. 322). Washington, DC: American Psychiatric Publishing.

Singh, K., \& Yu, N. X. (2010). Psychometric Evaluation of the Connor-Davidson Resilience Scale (CDRISC) in a Sample of Indian Students. Journal of Psychology, 1(1): 23-30.

Tabachnick, B. G., \& Fidell, L. S. (2007). Using Multivariate Statistics. 5th edition. Boston, MA: Pearson Education. Inc.

Thompson, N. (2019). A Climate Assessment of Working Environments at a Small Midwestern Public High School. Research Paper, University of Wisconsin-Stout.

Tullis, T., \& Albert, B. (2013). Self-Reported Metrics. Measuring the User Experience: Collecting, Analyzing, and Presenting Usability Metrics. Second Edition. US: Morgan Kaufmann.

Ungar, M., Brown, M., Liebenberg, L., Othman, R., Kwong, W.M., \& Armstrong, M. (2007). Unique pathways to resilience across cultures. Adolescence, 42(166), 287-310.

Wang, C. K., and Wong, P. K. (2004). Entrepreneurial interest of university students in Singapore. Technovation Journal, 24(2), 163-172.

Zautra, A. J., Hall, J. S., \& Murray, K. E. (2010). Resilience: A new definition health for people and communities. Handbook of Adult Resilience (pp. 3-30). New York: Guilford.

Zuraidah, Z. (2014). The Effects Of Custumer-Brand Relationship Invesment On Customer Engagement. Phd Thesis, Universiti Pendidikan Sultan Idris. 